\title{
Institutional Design and the New Systemic Risk in Banking Crises
}

\author{
Anita Anand, Michael J. Trebilcock and Michael Rosenstock
}

Version Post-print/accepted manuscript

Citation Anand, Anita and Trebilcock, Michael J. and Rosenstock, Michael,

(published version) Institutional Design and the New Systemic Risk in Banking Crises (May 14, 2014) http://dx.doi.org/10.2139/ssrn.2437217

How to cite TSpace items

Always cite the published version, so the author(s) will receive recognition through services that track citation counts, e.g. Scopus. If you need to cite the page number of the author manuscript from TSpace because you cannot access the published version, then cite the TSpace version in addition to the published version using the permanent URI (handle) found on the record page.

This article was made openly accessible by $U$ of $T$ Faculty. Please tell us how this access benefits you. Your story matters. 


\section{Institutional Design and the New Systemic Risk in Banking Crises}

Anita Anand, Michael Trebilcock and Michael Rosenstock

Faculty of Law

University of Toronto

Draft: May 14, 2014 


\section{Table of Contents}

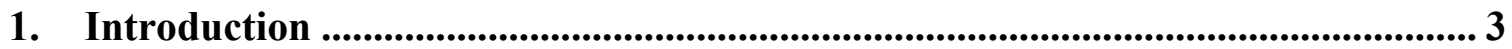

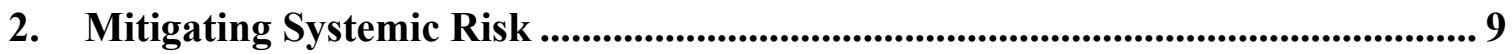

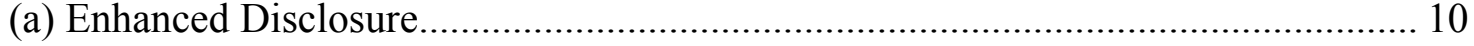

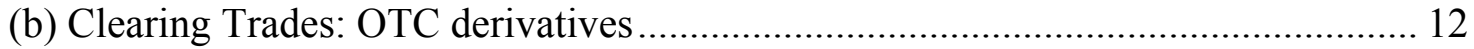

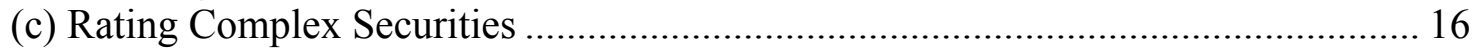



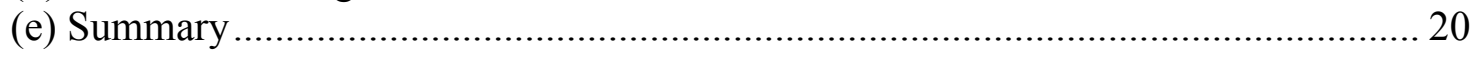

3. Institutional Design and Coordination ............................................................. 20

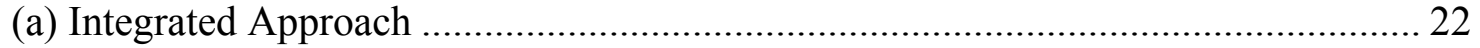

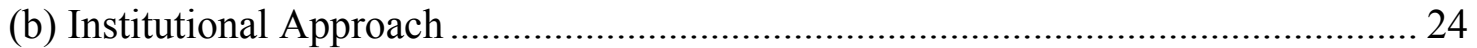

(c) Functional Approach...................................................................................... 26

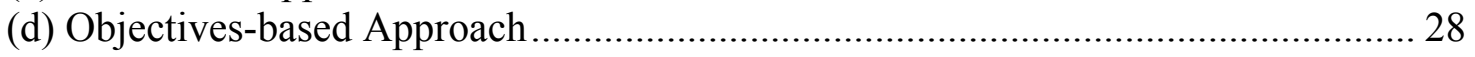

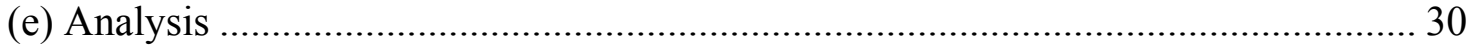

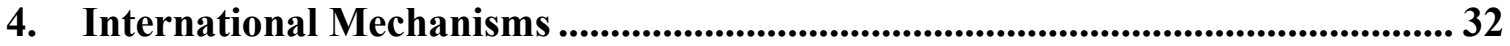

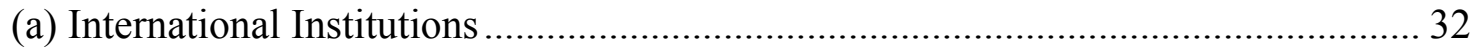

(b) Proposals for International Coordination and Enforcement ............................... 35

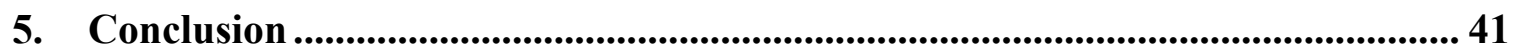




\section{Introduction}

Financial crises come in many shapes and forms. In a recent widely-acclaimed survey of eight centuries of financial crises around the globe, Reinhart and Rogoff helpfully categorize them as follows: sovereign defaults, which occur when a government fails to meet payments on its external or domestic debt obligations; banking crises, such as those the world has experienced since 2008, where a significant part of a country's banking sector has become insolvent after heavy investment losses; exchange rate crises, where the value of a country's currency falls precipitously; and, finally, crises marked by bouts of very high inflation that constitute the de facto equivalent of outright default on public or private sector debt. ${ }^{1}$ Reinhart and Rogoff argue that over history there are many similarities within each category of financial crises in terms of their causes and consequences. Moreover, it might be argued that across these categories, a common characteristic tends to be a dramatic and unsustainable expansion of credit, often fueled by external financial inflows reflecting global monetary imbalances. ${ }^{2}$

In this paper, we focus on banking crises, with a special focus on lessons to be learned from the global financial crisis that began in 2008, typified by the dramatic growth in the scale and complexity of financial instruments in wide use throughout the financial sector, the expansion of a "shadow" banking sector implicating solvency and liquidity concerns for many financial institutions beyond the traditional focus on the solvency and liquidity of commercial banks; major contagion effects across national borders, reflecting the internationalization of financial institutions and financial transactions; and finally, the engagement of a broader range of regulatory institutions, both domestic and institutional, beyond the traditional regulatory focus on the solvency and liquidity of commercial banks.

\footnotetext{
${ }^{1}$ See Carmen Reinhart and Kenneth Rogoff, This Time Is Different: Eight Century of Financial Folly (Princeton University Press, 2009). See also "The slumps that shaped modern finance" The Economist (April 12, 2014) 49-54.

${ }^{2}$ Ibid. Preface; See Charles Kindleberger and Robert Aliber, Manias, Panics and Crashes: A History of Financial Crises (Palgrave McMillan, New York, 2011, $6^{\text {th }}$ ed.), chapter 2.
} 
We argue that the concept of "systemic risk," which traditionally focused on the relative stability of financial institutions and the consequences of their failure, has evolved to include macroprudential risk and the possibility that an entire economy will be affected by a triggering event or exogenous shock. As a result of this evolution, regulators have an important role to play in monitoring and managing systemic risk. We explore key policy instruments and the complement of domestic and international institutions that most effectively enable financial market regulators to discharge their role in monitoring and managing this new conception of systemic risk, which we refer to as the "new systemic risk" (NSR).

We begin with an acknowledgement that existing academic literature can be divided into two camps. On the one hand are traditional definitions of systemic risk; these definitions center on counterparty contagion within the banking sector whereby one bank's default (on a loan, deposit or payment) to another bank occasions a loss greater than the second bank's capital, forcing the second bank to default on obligations to a third bank, occasioning a loss greater than the third bank's capital and so on. ${ }^{3}$ The concept of a domino or contagion effect that negatively impacts financial institutions is thus central to the traditional understanding of systemic risk.

On the other hand is the notion that such a "domino effect" will often occasion negative consequences not only for financial institutions (predominantly banks) but also for the financial system as a whole. ${ }^{4}$ Helwege explains that systemic risk is "the risk that the

\footnotetext{
${ }^{3}$ Andrew Crockett "Why Is Financial Stability a Goal of Public Policy?" in Maintaining Financial Stability in a Global Economy (Kansas City, MO: Federal Reserve Bank of Kansas City, 1997) at 7-36. There are notable "outliers"- examples of economists who define "systemic risk" differently pre-2008. For instance, De Bandt and Hartmann note that although "systemic risk" traditionally refers to vulnerability in the banking sector, "at the heart of the concept is the notion of 'contagion,' a particularly strong propagation of failures from one institution to another": Olivier de Bandt and Philipp Hartmann, "Systemic risk: a survey", (2000) European Central Bank Working Paper No. 35 at 8. Taylor similarly defines systemic risk as "macroeceonomic risk that the entire economy will be affected", including money supply and asset price shocks as potential sources of systemic risk: John Taylor, "Defining Systemic Risk Operationally" in George Shultz, Kenneth Scott \& John Taylor, eds, Ending Government Bailouts As We Know Them (California: Hoover Press, Stanford University, 2003) at 36-42.

${ }^{4}$ Hal S. Scott, "The Reduction of Systemic Risk in the United States Financial System" (2010) 33 Harv JL \& Pub Pol'y 671 at 675 ("Here the concern is that if institution $X$ fails to settle its derivative position with institution $\mathrm{Y}$, both $\mathrm{X}$ and $\mathrm{Y}$ will fail. If $\mathrm{Y}$ in turn cannot settle its positions, other institutions will also fail.”)
} 
financial system will fail to function properly because of widespread distress." Similarly, Billio et al define systemic risk as "any set of circumstances that threatens the stability of or public confidence in the financial system." Key policy-makers have now adopted a broader definition of "systemic risk." Mark Carney, past Governor of the Bank of Canada and current head of the Bank of England, as well as Ben Bernanke, former Federal Reserve Chairman, have defined systemic risk as some form of system-wide financial distress or disruption with significant consequences for the real economy. ${ }^{7}$

During the recent financial crisis, systemic consequences stemming from the failure of individual banks have been amplified with the banking sector's evolution from an "originate-to-hold" to an "originate-to-distribute" model. That is, banks have historically occupied the role of lender in issuing home mortgages or other credit instruments. Over time, they began not only to hold the risks but also to seek additional returns on loans by bundling mortgages and selling them to other (often non-bank) financial intermediaries. ${ }^{8}$ But when banks offloaded exposure to risks associated with loans, they had weaker incentives to scrutinize their borrowers. Furthermore, in ceasing to hold the loans, banks dispensed with their incentive to monitor borrowers as the loans matured. ${ }^{9}$

\footnotetext{
${ }^{5}$ Jean Helwege, "Financial Firm Bankruptcy and Systemic Risk" (2009) Regulation 24 at 24.

${ }^{6}$ Monica Billio, Mila Getmansky, Andrew W Lo, and Loriana Pelizzon, "Econometric measures of connectedness and systemic risk in the finance and insurance sectors" (2012) 104 Journal of Financial Economics 535 at 537.

${ }^{7}$ See Mark Carney, who describes systemic risk as "the probability that the financial system is unable to support economic activity": Mark Carney, cited in Nikil Chande, Nicholas Labelle, and Eric Tuer, Central Counterparties and Systemic Risk (Bank of Canada, Financial System Review, December 2001) at 1; Ben Bernanke, who advocates for a broad definition that includes "developments that threaten the stability of the financial system as a whole and consequently the broader economy": Corey Boles, "Bernanke offers broad definition of systemic risk" (18 Nov 2009) Wall Street Journal <online: wsj.com> Accessed 26 Oct 2013. We acknowledge that financial crises come in all kinds of forms. See Reinhart and Rogoff, supra note 1 (surveying 8 centuries of financial crises in different countries).

${ }^{8}$ See Kathryn Judge, "Fragmentation Nodes: A Study in Financial Innovation, Complexity, and Systemic Risk" (2012) 64 Stanford L Rev 657 at 671. See also Anita I Anand, "Systemic Risk and Securities Regulation" (2010) 60 University of Toronto Law Journal at 941 at 942 [Anand 2010].

${ }^{9}$ The bank originally acted as originator, recipient of monthly payments, and re-negotiator of the loan's terms. With securitization, banks were replaced by "servicers". Various scholars have argued that banks were better-suited to their previous role. See: Douglas W Diamond, "Financial Intermediation and Delegated Monitoring" (1984) 51:3 Review of Economic Studies 393; Bengt Holmström and Jean Tirole, "Market Liquidity and Performance Monitoring" (1993) 101:4 Journal of Political Economy 678; Ram TS Ramakrishnan \& Anjan V Thakor, "Information Reliability and a Theory of Financial Intermediation" (1984) 51:3 Review of Economic Studies 415.
} 
In fact, banks, especially in the U.S., devised innovative means of expanding the market for securitized loans. They began by securitizing more kinds of home loans, beyond those that Fannie Mae or Freddie Mac were allowed to acquire (while Fannie Mae and Freddie Mac sponsored pass-throughs, i.e. relatively simply securitizations with only prepayment risk). As the demand for mortgage backed securities increased, banks found yet more ways to securitize, culminating in highly complex sub-prime loan agreements underlying the securities. ${ }^{10}$ Judge explains that "[o]f the roughly $\$ 1.2$ trillion in sub-prime loans extended in 2005-2006, more than 80\% were subsequently securitized." ${ }^{11}$ Beyond securitizing mortgages, banks were increasingly distributing all kinds of loans: in 2007, the syndicated loan market rose from $\$ 339$ billion in 1988 to $\$ 2.2$ trillion and loan securitization reached $\$ 180$ billion. $^{12}$

Understanding that the concept of the NSR is more ubiquitous or at least more elusive relative to the paradigm of systemic risk that prevailed under traditional conceptions of such risk, we seek to answer two questions. First, what are some more prominent examples of policy instruments that are (or might be) required to respond to the NSR? Second, assuming that a broader range of policy instruments is required either to preempt or mitigate systemic risk (to the extent possible) - in much more fluid and less institutionally and functionally defined financial systems - what form of institutional or regulatory architecture is best adapted to the effective deployment of these instruments?

We argue for more integration and co-ordination among institutions charged with systemic risk oversight and regulation, both domestically and internationally, recognizing that the existing set of institutions developed at a time when a more restricted conception of systemic risk prevailed. Specifically, we favour an approach to regulation under which financial markets are regulated according to certain regulatory objectives that are

\footnotetext{
${ }^{10}$ For an account of their complexity and its attendant complication of the security, see Oren Bar-Gill, "The Law, Economics, and Psychology of Subprime Mortgage Contracts” (2009) 94 Cornell L Rev 1073 at 1078.

${ }^{11}$ Judge, supra note 8 at 679.

${ }^{12}$ Vitaly M. Bord \& João A.C. Santos, "The Rise of the Originate-to-Distribute Model and the Role of Banks in Financial Intermediation”, Federal Reserve Bank of New York Economic Policy Review (July 2012) 21 at 21-2.
} 
specified in the applicable legislation. ${ }^{13}$ Indeed, this approach identifies three basic regulatory objectives that the regulatory architecture must address: macro-economic stability typically associated with central banks in terms of implementing monetary policy and acting as lender of last resort in maintaining liquidity in the financial system; micro-prudential regulation which focuses on the financial stability of individual financial institutions; and conduct of business regulation designed to protect consumers of financial services and investors in financial institutions. We argue that this model benefits from coordination and cost advantages, while differentiating among objectives that are widely seen to require distinct regulatory strategies. ${ }^{14}$

Our argument builds on a growing body of literature that probes the concept of systemic risk. Anabtawi and Schwarcz, for example, argue that incentives to discount inter-firm and intra-firm risk-taking generate externalities on other market participants and increase systemic risk. ${ }^{15}$ Along similar lines, Hanson, Kashyap, and Stein show how financial institutions respond to market downturns by reducing the size of their asset base; the failure by each affected financial institution to internalize the social costs of their response drives system-wide credit freezes and significant declines in securities prices (i.e., "credit crunch" and "fire sales"). ${ }^{16}$ Gorton and Metrick describe the relationship between the growth of the shadow banking sector (particularly money market mutual funds, securitizations, and repurchase agreements) and systemic risk: sudden uncertainty about the position of financial institutions triggered the belief that these instruments, which are used as collateral in short-term lending arrangements, would be sold to meet

\footnotetext{
${ }^{13}$ Group of Thirty, "The Structure of Financial Supervision" (Washington, Group of Thirty, 2008) at 24. See also "Blueprint for a Modernized Financial Regulatory Structure" (2008) US Department of the Treasury at 142. The lines between categories may blur and some commentators use different terminology. For example, Wymeersch terms regulation-by-objective as the functional approach and places the "twin peaks" model within this category. See Eddy Wymeersch, "The Structure of Financial Supervision in Europe: About Single Financial Supervisors, Twin Peaks and Multiple Financial Supervisors" (2007) 8 European Business Organization Law Review 237 at 258.

${ }^{14}$ Eric J Pan, "Structural Reform of Financial Regulation" (2010-2011) 19 Transnational Law and Contemporary Problems 796 at 820.

${ }^{15}$ Iman Anabtawi and Steven L Schwarcz, "Regulating Systemic Risk: Towards an Analytical Framework" (2011) 86:4 Notre Dame Law Review 1349 at 1360 and 1382-1386.

${ }^{16}$ Samuel G Hanson, Anil K Kashyap and Jeremy Stein, “A macroprudential approach to financial regulation" (2011) 25 Journal of Economic Perspectives 3 at 6-7.
} 
various obligations - triggering a fire sale. ${ }^{17}$ Judge argues that the complexities stemming from financial innovations in securitization are a source of systemic risk that require a policy response beyond those taken by Dodd-Frank and other measures. ${ }^{18}$ These scholars are among others who have also noted the importance of systemic risk for prudential regulators in regulating today's financial markets and have proposed some form of regulatory restructuring. ${ }^{19}$

Our paper differs from this literature, however, in its recognition that the emergence of the NSR requires a serious rethinking of the institutional architecture for regulating systemic risk rather than simply focusing on prudential regulators alone. We do not argue for an overhaul of any one country's institutions but argue for greater emphasis on coordination among domestic financial regulators. Thus, the objectives-based approach, which focuses not on the creation or extinction of institutions themselves but on existing institutions' adherence to certain regulatory objectives, is fundamentally important. At the international level, we propose to address deficiencies in compliance with an increasing use of memoranda of understanding (MOU) among countries to bind them to a system of monitoring, management and enforcement of regulatory oversight of the NSR.

Our approach is unique in that we recognize a certain level of path dependency in the evolution and persistence of domestic institutions - the bodies tasked with making, administering and enforcing laws (governmental or non-governmental). ${ }^{20}$ Path dependency helps to explain why institutions that govern financial markets are difficult to alter because of set-up or fixed costs in establishing a new institution and switching or transition costs to the new institution, among other things. We draw upon the argument of Prado and Trebilcock that while path dependency can clarify what has happened in the past, it can also be used to inform the feasibility of institutional reforms. ${ }^{21}$ Rather than

\footnotetext{
${ }^{17}$ Gary Gorton and Andrew Metrick, "Regulating the Shadow Banking System” (2010) Brookings Papers on Economic Activity 261 at 269-280.

${ }^{18}$ Judge, supra note 8 at 691-717; Dodd-Frank Wall Street Reform and Consumer Protection Act, Pub. L. No. 111-203, § 929-Z, 124 Stat. 1376, 1871 (2010) (codified at 15 U.S.C. \& 78o) [Dodd-Frank].

${ }^{19}$ See generally Wymeersch, supra note 13; Pan, supra note 14; Scott, supra note 4.

${ }^{20}$ Mariano Prado and Michael J Trebilcock, "Path Dependence, Development and Dynamics of Institutional Reform" (2009) 59 UTLJ 342 at 346-349.

${ }^{21}$ Ibid at 353.
} 
suggest the amalgamation of institutions, or the creation of new regulators, we focus on the importance of ensuring that managing and monitoring systemic risk as an objective should be integral to a country's regulatory scheme.

As a new and more expansive conception of systemic risk, the NSR implicates more financial entities than traditional notions of systemic risk that focused on the prudential regulation of commercial banks. Hence, it stands to reason that the NSR implicates a broader range of potential regulatory instruments than merely setting prudential standards for commercial banks. We examine some of these tools in Part 2, including mandating disclosure, regulating over-the-counter (OTC) derivatives and overseeing credit rating agencies. In Part 3, we explore various institutional models to deploy these policy instruments, focusing on differing institutional arrangements in place in various jurisdictions and their respective strengths and weaknesses. In Part 4, we explore the role of international coordinating institutional mechanisms, including soft law initiatives, for addressing the effects of interjurisdictional systemic risks. Part 5 concludes our paper.

\section{Mitigating Systemic Risk}

Most countries have in place a regulator whose legislative purview is to focus on the financial soundness of individual financial institutions, such as banks and insurers. The regulator's typical role is to establish rules relating to risk management and capital adequacy and to intervene in cases of deficiency. ${ }^{22}$ Prior to the recent financial crisis, the idea that this regulator would also regulate the stability of the entire financial system and have carriage over "systemic risk" - was not a matter of debate, perhaps because financial system stability was understood solely to be "the sum of the safety and soundness of individual institutions. ${ }^{, 23}$ Following the crisis, however, it has become clear that financial institutions and the markets in which they function are intricately connected

\footnotetext{
${ }^{22}$ Nick Le Pan, "Look before you leap: A skeptical view of proposals to meld macro- and microprudential regulation" (2009) 296 CD Howe Institute at 1. Le Pan points to Canada's Office of the Superintendent of Financial Institutions (OSFI) as an example.

${ }^{23}$ Ibid at 1 (citing Claudio Borio "Towards a Macro-Prudential Framework for Financial Supervision and Regulation" (2003) Bank for International Settlements Working Paper and Bank for International Settlements, "78th Annual Report" (2008)).
} 
quite apart from whether any individual institution has sound risk management practices in place.

The G20 countries and the International Organization of Securities Commissions (IOSCO) thus called for additional regulation to address systemic risk, including greater coordination among all financial market regulators in an effort to address concerns of the NSR. ${ }^{24}$ A host of policy instruments designed to address the NSR has emerged throughout common and civil law countries. As discussed below, some of these instruments have included increasing disclosure obligations, regulating OTC derivatives, monitoring credit rating agencies, and developing a regulatory approach to shadow banking.

\section{(a) Enhanced Disclosure}

It is generally recognized that a shock to the US subprime mortgage market triggered major declines in higher-rated asset backed securities and other markets as investors lacked sufficient information to evaluate adequately the riskiness of the financial products they held. ${ }^{25}$ Comprehensive disclosure may have better enabled investors to ascertain asset quality, thus reducing the impact of panicked investor responses to a failure of financial products on the broader market. ${ }^{26}$ As an immediate response to the financial crisis, therefore, scholars, regulators, and international organizations have proposed stronger disclosure requirements for financial products. $^{27}$

\footnotetext{
${ }^{24}$ G20 Leaders Statement, "Declaration of the Summit on Financial Markets and the World Economy" (15 Nov 2008) Washington, DC at para 9; G20 Leaders Statement, "The Pittsburgh Summit" (24-25 Sep 2009) Pittsburg, PA at para 9; International Organization of Securities Commissions, "IOSCO Open Letter to G20 Summit" (12 Nov 2008) Media Release.

${ }^{25}$ Scott Hendry, Stéphane Lavoie, and Carolyn Wilkins, "Securitized Products, Disclosure, and the Reduction of Systemic Risk" (2010) Bank of Canada - Financial System Review 47 at 49. See also Gorton and Metrick, supra note 17 at 268.

${ }^{26}$ Hendry et al, supra note 23 at 48.

${ }^{27}$ See e.g. Anand (2010), supra note 8 at 963; Anabtawi and Schwarcz, supra note 15 at 1383-84; Technical Committee of the International Organization of Securities Commissions, "Mitigating Systemic Risk: A Role for Securities Regulators" (2011) International Organization of Securities Commissions at 43.
} 
Of course, disclosure obligations for public issuers of asset-backed and other securities long predate the financial crisis. Issuers are responsible for meeting various prospectus and continuous disclosure requirements, including providing "full, plain, and true disclosure of all material facts" and reporting material changes. ${ }^{28}$ However, securities regulators historically allowed complex securities like short-term asset-backed commercial paper to be issued on the exempt (or private) market - that is, exempt from the disclosure obligations that apply to publicly issued asset-backed securities - provided they were rated by a credit rating agency. ${ }^{29}$ This approach was based on the notion that investors in these financial products were large institutional investors with the capacity and incentives to conduct necessary due diligence. ${ }^{30}$ Several authors persuasively argue that the financial crisis and freeze of the $\$ 30$ billion asset-backed commercial paper market in Canada show that even sophisticated investors lack the incentives or capacity to invest in desirable levels of information. ${ }^{31}$

Regulators have responded by increasing disclosure requirements for asset-backed securities, broadening the definition of securitized products such that more products fell within the scope of regulation, consequently ending many of the exemptions for private issuers. ${ }^{32}$ Under Dodd-Frank ${ }^{33}$ and accompanying SEC regulations, ${ }^{34}$ the United States adopted ongoing disclosure requirements for asset-backed securities, standardized disclosure requirements to facilitate comparison of assets of similar classes and required the release of specific asset-level data, including the degree of risk retention by the

\footnotetext{
${ }^{28}$ Ontario Securities Act, RSO 1990 c S5 at s 56(1) and National Instrument [52-101]; See also UK Financial Conduct Authority, "Disclosure Rules and Transparency Rules", Financial Conduct Authority Handbook (Release 146) (2014) at 2.1.3; Securities Act of 1933, Pub L No 112-106, §7 and §10; Australia Corporations Act 2001 (Cth) at Div 2.

${ }^{29}$ Anand (2010), supra note 8 at 944; Hendry et al, supra note 23 at 49

${ }^{30}$ Hendry et al, supra note 23 at 49.

31 John Chant, "The ABCP Crisis in Canada: The Implications for the Regulation of Financial Markets" Research Study Prepared for the Expert Panel on Securities Regulation at 22.

${ }^{32}$ See e.g. Dodd-Frank, supra note 18 at H.R. 4173-522; (2011) 34 OSCB 3819 (Removal of existing prospectus exemptions).

${ }_{33}$ Dodd-Frank, supra note 18 at H.R. 4173-522.

${ }^{34}$ Securities and Exchange Commission, "Disclosure for Asset-Backed Securities Required by Section 943 of the Dodd-Frank Wall Street Reform and Consumer Protection Act" (28 Mar 2011) 17 CFR Parts 229, 232,240 and 249.
} 
sponsor and compensation provided to the broker. ${ }^{35}$ These measures were designed to provide necessary information for investors to conduct due diligence and reduce the likelihood of market contagion. Other countries explored similar measures, including the form that disclosure should take in order to be understandable to investors. ${ }^{36}$

Poor disclosure of complex securities was only one aspect of the market failure that warranted additional regulatory intervention. As several commentators explain, the complexity of financial instruments limits the effectiveness of disclosure, as even sophisticated investors may be unable to conduct a proper valuation. ${ }^{37}$ At the heart of the crisis were complex derivatives, such as Credit Default Swaps (CDSs), whose distribution was facilitated by market players, including credit rating agencies and dealers. Financial market regulators needed to develop mechanisms to address both complex derivatives and those who facilitated their trading. We turn now to examine these mechanisms.

(b) Clearing Trades: OTC derivatives

Beginning in the 1980s, the market for over-the-counter (OTC) derivatives in the U.S. grew rapidly; the value of financial derivatives rose from $\$ 3.2$ trillion in 2000 to $\$ 20$ trillion in 2008 (gross market value) ${ }^{38}$ in part a result of the effective deregulation of

\footnotetext{
${ }^{35}$ See also Technical Committee of the International Organization of Securities Commissions, "Principles for Ongoing Disclosure for Asset-Backed Securities - Consultation Report" (2012) International Organization of Securities Commissions at 34-35 [IOSCO ABS Consultation Report 2012]

${ }^{36}$ In Canada, see, for example, Form 41-103F 1 - Supplementary Information Required in a Securitized Products Prospectus, (2011) 34 OSCB 3835 ; See also Michael K Feldman, "Slow and Steady Wins the Race" (2011) Summer/Fall American Securitization at 32. Like Canada, the Bank of England and European Central Bank have raised disclosure standards by demanding that asset-backed securities used as collateral include specific data on the underlying asset, meet prospectus requirements, and cash flow projections. See also IOSCO ABS Consultation Report 2012, supra note 35 at 33-34.

${ }^{37}$ For a pre financial crisis view of the limitations of disclosure, see Steven L Schwarcz, "Rethinking the Disclosure Paradigm in a World of Complexity" (2004) University of Illinois Law Review 1 at 11-17; Judge makes a similar point about mortgage backed securities in the post financial crisis context: Judge, supra note 8 at 713 .

${ }^{38}$ Financial Crisis Inquiry Commission, "Financial Crisis Inquiry Commission Report" (Washington, DC: US Government Printing Office, 2011) at 29 [Financial Crisis Inquiry Commission].
} 
financial derivatives by the United States in 2000. ${ }^{39}$ Businesses and financial institutions used these securities to manage risk. ${ }^{40}$ Credit default swaps (CDSs), for example, were used as an insurance-like instrument in which one party assumed credit risks associated with a particular debt instrument (e.g., mortgage-backed securities) in exchange for payments over the lifecycle of that debt. ${ }^{41}$ High leverage, limited collateral, and the interconnectedness of parties meant that if one participant was unable to settle its position with its counterparty, the ability of the counterparty to settle other derivative positions was put into question, and so forth. ${ }^{42}$ It was the failure to clear the significant OTC derivative holdings of AIG and Lehman Brothers that set off domino reactions across financial institutions and ultimately led to the collapse of Lehman Brothers in September $2008 .^{43}$

One of the main difficulties with OTC derivatives, however, is that (by definition) they do not trade through a central clearing platform, ${ }^{44}$ but rather are completed via contractual bilateral relationships between parties. As a policy response to these events, the G20 agreed to require participants to report derivatives transactions to trade depositories, ${ }^{45}$ and mandated central counterparty (CCP) clearing and settlement of standardized OTC derivatives. ${ }^{46}$ Under CCP clearing, the clearinghouse acts as the counterparty to a transaction between financial participants, providing an effective

\footnotetext{
${ }^{39}$ Financial Crisis Inquiry Commission, supra note 38 at 48. See also Lynn A Stout, "Why re-regulating derivatives can prevent another disaster" (21 Jul 2009) Harvard Law School Forum on Corporate Governance and Financial Regulation <online: http://blogs.law.harvard.edu> Accessed 21 Oct 2013.

${ }^{40}$ Adam R Waldman, "OTC Derivatives \& Systemic Risk: Innovative Finance or Dance into the Abyss?" (1994) 43 American University Law Review 1023 at 1038.

${ }^{41}$ Financial Crisis Inquiry Commission, supra note 38 at 50, xxiv; Anabtawi and Schwarcz, supra note 15 at 1372 ("Derivatives, most notably credit-default swaps... allow firms to trade credit risks on a variety of exposures.")

${ }^{42}$ Scott, supra note 4 at 675; Anabtawi and Schwarcz, supra note 15 at 1372.

${ }^{43}$ Gertrude Tumpel-Gugerell, "Why OTC derivatives must be cleared", Financial Times (22 Jun 2010) Financial Times Online <online: ft.com> Accessed 29 Sep 2013.

${ }^{44}$ Nikil Chande, Jean-Philippe Dion, Darcey McVanel, and Joshua Slive, "The Canadian Approach to Central Clearing for Over-the-Counter Derivatives" (2012) Bank of Canada Financial System Review 43 at 43.

${ }^{45}$ OTC Derivatives Regulators Group, "Report on Agreed Understandings to Resolving Cross-Border Conflicts, Inconsistencies, Gaps and Duplicative Requirements", US Commodity Future Trading Commission, August 30, 2013 at 3.

${ }^{46}$ Basel Committee on Banking Supervision and Board of International Organization of Securities Commissions, "Margin requirements for non-centrally cleared derivatives" (September 2013) at 1.
} 
guarantee that transactions will settle. ${ }^{47}$ The risk absorbed by the clearinghouse is funded through margin and capital requirements, essentially pooling the risk of derivatives contracts across all transactions. ${ }^{48}$ While the shift to CCP clearing raises costs for participants by requiring them to meet margin (collateral) requirements, the objective is to achieve a level playing field across participants at a modest cost, ${ }^{49}$ while dismantling the interconnectedness among market participants. ${ }^{50}$

Non-standardized OTC derivatives represent a substantial proportion of the derivatives market. ${ }^{51}$ Because they are customized, they are difficult to price and also face liquidity constraints. They are therefore less suited to CCP clearing mechanisms and pose a challenge to leveling the playing field. ${ }^{52}$ The G20 agreed to substitute CCP clearing requirements with minimum margin and capital requirements for these securities. ${ }^{53}$ The aim was to create a disincentive for participants to migrate away from the CCP clearing system to a less costly model, in addition to lowering individual and systemic risk. ${ }^{54}$

As will be discussed in Part 4, effective implementation of international standards, including G20 recommendations, depends on the individual country and its financial regulators. Unsurprisingly, jurisdictions have adopted differing approaches to implementing these requirements ${ }^{55}$ with regulators' roles dramatically shifting from virtually no oversight of derivatives contracts ${ }^{56}$ to, in most jurisdictions, managing the registration of dealers, advisers, and participants; acting as a repository for derivatives trades; overseeing CCP clearinghouses; and, given the international nature of the

\footnotetext{
${ }^{47}$ Anabtawi and Schwarcz, supra note 15 at 1394.

${ }^{48}$ Scott, supra note 4 at 688 .

${ }^{49}$ Basel Committee, supra note 44 at 3-4.

${ }^{50} \mathrm{Scott}$, supra note 4 at 687-688.

${ }^{51}$ Basel Committee, supra note 44 at 2.

${ }^{52}$ Scott, supra note 4 at 688-690.

${ }^{53}$ See Basel Committee, supra note 44 at 25.

${ }^{54}$ Ibid at 3.

55 There is, however, general uniformity in terms of implementing trade repository requirements. Europe requires that all derivative contracts - OTC and non-standardized - must be reported. See Benoit Coeuré, "Four Years After Pittsburgh: What has the OTC Derivatives Reform Achieved So Far", Speech to Joint Banque de France, Bank of England, and ECB Conference on OTC Derivatives Reform, European Central Bank, 11 Sep 2013.

${ }^{56}$ In Canada, for example, many provincial securities regulators did not initially have legislative authority to regulate the OTC derivatives market. See Mary Condon, "Canada’s Role in Expanded IOSCO Principles” (9 Jul 2012) Toronto Securities Leadership Seminar at 13.
} 
derivatives market, coordinating the regulation of derivatives with regulators in other jurisdictions.

But these varying approaches do not necessarily facilitate seamless trading and oversight of OTC derivatives using CCP across borders. In the United States, for example, DoddFrank and related guidelines require registration and central clearing of most swaps by US persons (broadly defined) and counterparties, ${ }^{57}$ and assign regulation of securitiesbased swaps markets to the SEC and other swaps to the Commodity Futures Trading Commission (CFTC) ${ }^{58}$ Canada, on the other hand, authorized federally-regulated Canadian derivatives market participants to meet regulatory requirements through regulated CCP clearing mechanisms outside of Canada. ${ }^{59} \mathrm{UK}$ regulators oversee Clearnet - a UK-based clearinghouse that clears most of the interest rate swaps used by Canadian banks. ${ }^{60}$

How to address the regulation of OTC derivatives, including the clearing of trades, has been an issue that has persisted in the years following the crisis. There is little agreement among countries regarding harmonizing the regulation of cross-border OTC derivative transactions: how should countries implement G20 commitments in a manner that is appropriate for their own markets? ${ }^{61}$ The need to ensure that information is shared among international regulators as well as cooperation agreements with these regulators, foreign trade repositories and CCPs remain outstanding issues. ${ }^{62}$ In concept, mandating central clearing and establishing trade repositories means little if domestic regulators cannot coordinate the implementation of these requirements.

\footnotetext{
${ }^{57}$ Dodd-Frank, supra note 18 at Part II - ss 721-774; US Federal Register - Part II Commodity Futures Trading Commission Vol 78 (26 July 2013) at 45317 ("the Commission would expect that a non-U.S. person whose swap dealing transactions with U.S. persons exceed the de minimis threshold would register as a swap dealer. Likewise, under the Proposed Guidance, the Commission would expect that a non-U.S. person who holds swaps positions where one or more U.S. persons are counterparties above the specified MSP thresholds would register as an MSP.")

${ }_{58}^{58}$ Dodd-Frank, supra note 18 at ss 721,761 .

59 "Statement by Canadian authorities on clearing of standardized OTC derivatives contracts" (1 Oct 2012) News Release, Bank of Canada; Chande et al, supra note 44 at 44.

${ }^{60}$ Chande et al, supra note 44 at 49.

${ }^{61}$ Canadian Securities Administrators, "Consultation Paper 91-401 on Over-the-Counter Derivatives Regulation in Canada" (2 Nov 2010) at 1.

${ }^{62}$ Ibid.
} 
(c) Rating Complex Securities

One of the reasons that certain tranches of CDOs were attractive to investors was that they carried Triple-A ratings from what appeared to be reputable credit-rating agencies (CRAs). In hindsight, it seems surprising that CRAs historically operated with no regulatory oversight since these were the institutions that rated the complex derivative securities that ultimately triggered the collapse or near collapse of financial institutions including Lehman Brothers and AIG. ${ }^{63}$ Canada, US, Australia and the UK have adopted a number of rules designed to mitigate conflicts endemic to credit rating agencies (CRAs), including mandatory registration and oversight. ${ }^{64}$

The key issue for each of these countries in regulating CRAs involves conflicts of interest inherent in the rating process. A company will hire a CRA to rate its debt in return for a fee. The CRA provides the rating but perhaps also seeks to maintain a longer-term relationship with the company. CRAs have an incentive to provide a rating with which the issuer is satisfied. This incentive can undermine CRAs' neutrality as arm's length agencies that offer objective assessments of the creditworthiness of the securities. Furthermore, the monetary incentives for providing favourable ratings have grown with the market for CDOs, because expected revenue from these ratings would also correspondingly increase.

Legislation enacted after the crisis to regulate CRAs required CRAs to register with securities regulators, to manage conflicts of interest and the inappropriate use of information, appoint a compliance officer, and annually file a report relating to these activities. Once designated, rating agencies would become subject to potential

\footnotetext{
${ }^{63}$ Anand (2010), supra note 8 at 973.

${ }^{64}$ (2012) 35 OSCB 913 National Instrument 25-101 - “Designated Rating Organizations” (Canada) [DROs]; Regulation No 1060/2009 of the European Parliament and of the Council (16 Sep 2009) Official Journal of the European Union L302/1 (Europe, including the UK); 09-224MR (Nov 2009) Australian Securities and Investments Commission (Australia); Dodd-Frank, supra note 18 at HR 4173-497 (United States).
} 
enforcement actions and compliance reviews. ${ }^{65}$ But legislation throughout common law jurisdictions generally does not address the core conflict of interest - i.e., the issuer that pays for the rating is the issuer that also receives the rating. CRAs are required to "register" with securities regulators, but such registration does not mean that conflicts have been eradicated: if CRAs are unable to eliminate a conflict, it is required only to "manage and disclose" it. ${ }^{66}$

Conflicts affect ratings, and objective ratings in particular. Further, the new legislation does not speak to the role that CRAs could and should play in alerting investors to potential systemic risk concerns that can arise from a particular instrument that they are rating. It does not oversee the content or methodology of ratings; even with a compliance officer in place and an annual report filed with securities regulators, investors could continue to lack full and accurate information regarding the securities they are purchasing. Finally, across jurisdictions, it is not clear what if any sanctions are in place for those who fail to comply with the new rules. While the regulation of CRAs implemented post crisis fills a gap in the securities regulatory framework, securities regulators have an unfinished agenda in this area. ${ }^{67}$

\section{(d) Shadow Banking}

The migration of financial institution activity from the formal regulated banking sector to the shadow banking system - a term that describes all non-bank lending such as corporate and private debt - has been extensive. ${ }^{68}$ In the United States, the ratio of assets held off

\footnotetext{
65 (2012) 35 OSCB 913 National Instrument 25-101 - "Designated Rating Organizations" (Canada).

66 Technical Committee of the International Organization of Securities Commissions, "Code of Conduct Fundamentals for Credit Rating Agencies" (2008) International Organization of Securities Commissions at 7 ("A CRA should adopt written internal procedures and mechanisms to (1) identify, and (2) eliminate, or manage and disclose, as appropriate, any actual or potential conflicts of interest").

${ }^{67}$ See generally Technical Committee of the International Organization of Securities Commissions, "Credit Rating Agencies: Internal Controls Designed to Ensure the Integrity of the Credit Rating Process and Procedures to Manage Conflicts of Interest" IOSCO Consultation Report (2012).

${ }^{68}$ Gorton and Metrick define the shadow banking sector as including, for example, money market mutual funds, investment banks, mortgage brokers, and instruments such as securitizations and repurchase agreements: Gorton and Metrick, supra note 17 at 261-262. See Edward McBride, "Shadow and Substance" (10 May 2014) The Economist at 4-6.
} 
bank balance sheets rose to 60 percent in 2007 from nil in $1980 .{ }^{69}$ Globally, shadow lending now constitutes at least one-quarter of all financial assets. ${ }^{70}$ Shadow banking has grown even more significantly after the financial crisis. Banks have responded to higher capital requirements and regulatory efforts that limit their capacity to engage in offbalance sheet transactions (see below) by reducing lending to individuals and businesses, creating incentives for non-bank intermediaries to assume that role. ${ }^{71}$

Despite its name, shadow banking is not inherently problematic: there are obvious economic benefits in expanded access to credit, especially when such non-bank lending is not implicitly the subject of government guarantees. ${ }^{72}$ Further, a wider spectrum of lenders can reduce systemic risk by "disseminating risks beyond the banks". ${ }^{73}$ However, several aspects of the shadow banking system - many of which involving efforts by banks to migrate away from the formal banking sector - were brought to light in the financial crisis and have since attracted the scrutiny of regulators.

The securitization and subsequent trading in mortgages (and other forms of debt) were one such area. Loans were divided risk into "tranches" and sold to investors; Triple A tranches are particularly suited to international demand for safe assets and yield. ${ }^{74}$ In the event of default (or other credit event) among individual loans, investors holding the safest tranche received priority to associated cash flows. ${ }^{75}$ The aggregation of securities into Triple A tranches diminished the incentive for market participants to invest in information about the quality of individual assets. ${ }^{76}$ More generally, securitization has given rise to perverse incentives among market participants (e.g., dealers, brokers, credit rating agencies, sponsors), inadequate risk management practices, and lack of disclosure. $^{77}$

\footnotetext{
${ }^{69}$ Gorton and Metrick, supra note 17 at 265.

${ }^{70}$ McBride, supra note 68 at 5.

${ }^{71}$ Ibid at 4-5.

${ }^{72}$ Ibid at 5 .

73 "Do it Right", (10 May 2014) The Economist at 16.

${ }_{75}^{74}$ See Diamond and Rajan, supra note 5 at 606-607.

${ }^{75}$ Financial Crisis Inquiry Commission, supra note 38 at 43.

${ }^{76}$ Hanson et al, supra note 16 at 16.

${ }^{77}$ Technical Committee of the International Organization of Securities Commissions, "Unregulated Financial Markets and Products" (Sep 2009) International Organization of Securities Commissions at 15.
} 
In response, IOSCO has proposed a set of broad principles governing the regulation of securitization practices, including requiring originators of securitizations to retain credit risk in the security, better disclosure (transparency and standardization), and independent evaluation of the performance of the underlying assets. ${ }^{78}$ Dodd-Frank requires securitizers (sponsors) to retain at least 5 percent of the credit risk associated with the security, ${ }^{79}$ unless the security is a high quality loan, in which case only underwriting standards apply. ${ }^{80}$ European regulators have instituted similar credit retention requirements, but without the exempting provisions. ${ }^{81}$ Canadian securities regulators have proposed disclosure requirements on securitizations but have not adopted similar provisions on credit risk retention. ${ }^{82}$

These transactions have been a concern for regulators not least because of the fact that the complexity created by securitization is itself a new source of the NSR. ${ }^{83}$ This complexity arises from the increased chain between the investor and the economic return; the competition between investors arising out of "waterfall" or distribution provisions; the limited consequences of the failure of the underlying asset for investors with priority claims; and the process of multiple securitizations that further stretches the connection between investor and underlying asset. ${ }^{84}$ While international regulators note the benefits of the securitization process in terms of diversifying and apportioning risks, ${ }^{85}$ the failure of the mortgage-backed security market during the financial crisis and dramatic

\footnotetext{
${ }^{78}$ Ibid at 21.

${ }^{79}$ Dodd-Frank, supra note 18 at HR 4173 516-517. (s 15G)

80 "High quality" includes home, auto, and commercial real estate loans. See "Global Developments in Securitization Regulation” (2012) Board of the International Organization of Securities Commissions, International Organization of Securities Commissions at 12.

81 "Global Developments in Securitization Regulation" (2012) Board of the International Organization of Securities Commissions, International Organization of Securities Commissions at 14.

${ }^{82}$ See generally Proposed National Instrument 41-103 (Supplementary Prospectus Disclosure Requirements for Securitized Products), 51-106 (Continuous Disclosure Requirements for Securitized Products), 52-109 (Certification of Disclosure in Issuers Annual and Interim Filings) 45-106 (Prospectus and Registration Exemptions), 45-102 (Resale of Securities) - "Notice and Request for Comments" (1 Apr 2011) Ontario Securities Commission.

${ }^{83}$ Judge, supra note 8 at 691-692, 701-702.

${ }^{84}$ Ibid at 685 .

${ }^{85}$ Technical Committee of the International Organization of Securities Commissions, "Unregulated Financial Markets and Products" (Sep 2009) International Organization of Securities Commissions at 15.
} 
consequences in terms of systemic risk have led regulators to reconsider securitization's historically unregulated status. ${ }^{86}$

\section{(e) Summary}

The above is not an exhaustive list of policy instruments to address the NSR that have been introduced since the financial crisis. We note first that financial institutions beyond commercial banks may create systemic risk and second, that a greater number of regulatory instruments than those implemented by prudential regulators are engaged. We turn now to examine a third issue: that monitoring and regulating the NSR involves regulatory institutions other than prudential regulators, both domestically and internationally, and these regimes pose novel challenges of regulatory integration/coordination within and across geographical borders.

\section{Institutional Design and Coordination}

In the previous section, we outlined various substantive areas of financial market activity that have warranted regulation or oversight on the part of securities regulators in order to address the NSR. These areas range from ensuring greater disclosure, to maintaining a clearing facility for OTC derivatives to regulating credit rating agencies. In this section, we move to a discussion of institutional design: which approach to regulating financial markets offers the most promise for regulating the NSR? ${ }^{87}$ As we see in the analysis of the approaches, much of the potential for regulating systemic risk depends on the coordination capacity of regulators within a country, except where a single entity is

\footnotetext{
${ }^{86}$ See generally ibid at 13 .

${ }^{87}$ The debate surrounding the merits of objectives-based or integrated regulatory structures appears to have emerged in the early 1990s in debates over the future of UK financial regulation. The debate centred around, inter alia, (a) perceived conflicts in the Bank of England's role in managing systemic risk and protecting depositors, and (b) the belief that the institutional approach was inadequate given the rise of major non-bank financial institutions. To address concerns, some had proposed a single agency. Others, such as Michael Taylor, proposed the creation of one commission to monitor prudential regulation (and systemic risk), and a second commission to undertake business conduct regulation. The Bank of England would remain independent and carry out monetary policy. Taylor termed this form of objectives-based regulation "Twin Peaks", based on the television program: Michael Taylor, "Twin Peaks': A regulatory structure for the new century" (1995) Centre for the Study of Financial Innovation.
} 
charged with the responsibility for regulating all facets of financial markets.

Before we begin, we note the importance of path dependency to our analysis. In the development context, Prado and Trebilcock argue that despite strong empirical evidence showing that institutions are key determinants of economic and social development, and international support for reforms, institutional reform in developing countries has proven extremely difficult. ${ }^{88}$ The authors explain these disappointing outcomes in terms of path dependency, a term that "describes how the reinforcement of a given set of arrangements over time raises the cost of changing them." persist when there are: significant fixed costs associated with change; "learning effects" which reward knowledge of a particular practice; the prospect of coordination costs; and finally, expectations or preferences that solidify around the status quo. ${ }^{90}$ The selfreinforcing characteristic implies increasing returns to institutional structures, practices or norms while switching costs associated with institution reform can be expected to rise over time. Pierson explains that increasing returns implies that small events can have significant long-term consequences ("critical junctures"), ${ }^{91}$ timing and political "inertia" are central, but change will usually be incremental. ${ }^{92}$

We apply this argument to the issue of financial system design. While the financial crisis (including the collapse of major investment banks) may have indicated that some form of reform is necessary to the complement of regulators governing our financial system, arguments from path dependency suggest that grand transformative changes are unlikely - or at least uncertain - and not necessarily a function of the severity of the crisis or the country at issue. But we can, and should, highlight the possibility of incremental reforms, including the legal objectives which existing regulatory institutions are charged with pursuing.

\footnotetext{
${ }^{88}$ Prado and Trebilcock, supra note 20 at 346-349.

${ }^{89}$ Ibid at 350 .

${ }^{90}$ Ibid at 351. See also Paul Pierson, "Increasing Returns, Path Dependence, and the Study of Politics" (2000) 94:2 American Political Science Review 251 at 254.

${ }^{91}$ See Prado and Trebilcock, supra note 20 at 357.

92 Paul Pierson, Politics in Time (Princeton, NJ: Princeton University Press, 2004) at 44, 153.
} 


\section{(a) Integrated Approach}

The integrated approach tasks a single entity with the regulation of financial markets, including banking and insurance, microprudential regulation ${ }^{93}$ and business conduct. ${ }^{94}$ In addition to the benefits related to administrative simplicity and cost-minimization, its main strengths rest in eliminating regulatory gaps, ensuring regulatory consistency and limiting the opportunities for regulatory arbitrage. ${ }^{95}$ Integration in theory creates comprehensive financial regulation since one body is administering all of the rules and procedures.

Integration is a regulatory response to financial innovation that blurred the lines between historically divided financial activities. ${ }^{96}$ For example, the securitization by banks of home or auto loans and the development of so-called "bancassurance" - the merger of banking and insurance services - seemed to demand a combined regulatory approach. ${ }^{97}$ The appeal was that integration would reduce inter-agency coordination problems by providing the regulator with a broader view of a firm's financial activity from an individual investor, firm-level and systemic perspective. ${ }^{98}$

Currently only one country in the G20, Ireland, operates under an integrated structure. ${ }^{99}$ All aspects of Ireland's financial sector are regulated through the Irish Central Bank. Singapore, a non-G20 common law jurisdiction, has an integrated model and until recently, the UK did so also. Until massive market reform in 2012, the UK's Financial Services Authority (FSA) supervised financial markets, securities regulation and the

\footnotetext{
93 See Richard J Herring and Jacopo Carmassi, "The Structure of Cross-Sector Financial Supervision" (2008) 17 Financial Markets, Institutions, \& Instruments 51 at 52-53, 63.

${ }^{94}$ Group of Thirty, supra note 13 at 24. See also Wymeersch, supra note 13 at 251-268. Some authors refer to the integrated approach as the "single (or unified)" approach. See Herring and Carmassi, supra note 93 at 57.

95 Pan, supra note 14 at 819; Herring and Carmassi, supra note 93 at 65.

${ }^{96}$ Wymeersch, supra note 13 at 278.

${ }^{97}$ Group of Thirty, supra note 13 at 21; Wymeersch, supra note 13 at 263.

${ }^{98}$ Group of Thirty, supra note 13 at 36.

${ }^{99}$ The Group of Thirty refers to Canada an integrated model, which may be incorrect given the structure of securities regulation: Group of Thirty, supra note 13 at 14; Ireland Central Bank Reform Act 2010 Ireland No 23; Wymeersch, supra note 13 at 295.
} 
prudential oversight of banks, investment firms, and insurers while the Bank of England carried out market stability functions.

While there are obvious coordination benefits in this model, the model also exhibits weaknesses. Some have argued that integration may send negative signals to the market. For example, regulating financial supervision and deposit guarantees together might signal to market participants that all regulated institutions are government-backed, creating a lower disciplining effect (i.e. more moral hazard). ${ }^{100}$ Other concerns, more prevalent in large jurisdictions, relate to the possible creation of a megaregulator that is of "unmanageable" magnitude ${ }^{101}$ - a key concern identified in the US context. ${ }^{102}$

But the biggest risk to having an integrated or single regulator is the potential for conflict between and among objectives, all of which may be critical for the functioning of a country's financial system. ${ }^{103}$ For example, while securities regulation has investor protection as one of its primary mandates, prudential regulation focuses on the stability of financial institutions; the two objectives may not always lead to consistent policy choices. Indeed, timely disclosure is central to the former, but may compromise the achievement of the latter.

This issue was the main reason that the UK reformed its integrated structure ${ }^{104}$ as indicated in comments made by George Osborne, Chancellor of the Exchequer, who stated, "The Bank of England was mandated to focus on consumer price inflation to the exclusion of other things. The Treasury saw its financial policy division drift into a backwater. The FSA became a narrow regulator, almost entirely focused on rules based regulation." 105 Thus, criticizing the structure as inadequately regulating the practices that

\footnotetext{
${ }^{100}$ US Department of the Treasury, supra note 13 at 141; Wymeersch, supra note 13 at 278.

${ }^{101}$ Wymeersch, supra note 13 at 268.

102 US Department of the Treasury, supra note 13 at 141.

${ }^{103}$ Pan, supra note 14 at 819; See also The Turner Review: A Regulatory Response to the Global Banking Crisis" (2009) UK Financial Services Authority" at 92; Taylor, supra note 81.

${ }^{104}$ See generally "Memorandum of Understanding between HM Treasury, the Bank of England and the Financial Services Authority", Financial Services Authority, 22 Mar 2006. See also Group of Thirty, "The Structure of Financial Supervision" (Washington, Group of Thirty, 2008) at 24, 28.

${ }^{105}$ Rt Hon George Osborne, Chancellor of the Exchequer, Speech at Lord Mayor's Dinner for Bankers and Merchants of the City of London, 16 Jun 2010, HM Treasury. See also "UK Financial Regulation
} 
gave rise to bank collapses and severe systemic risk, Parliament enacted the Financial Services Act, 2012, ${ }^{106}$ which replaced the FSA with a "twin peaks" regulatory structure, described below. ${ }^{107}$

In short, the objectives of financial regulation can be inconsistent, complex and numerous and it will be difficult if not impossible for a single regulatory authority to prioritize the objectives even with legislative guidance. ${ }^{108}$ Furthermore, in the event that the integrated regulator determines that it does not have a role to play in any given financial market event, or simply overlooks a market event that warrants regulatory attention, there are no other regulatory bodies to fill regulatory gaps. In other words, there is a paucity of regulatory checks and balances in a system with only one financial market regulator in place. These factors lend support for alternative regulatory structures with separate institutions charged with differing tasks, all of which are important to the functioning of a financial system and the regulation of the NSR. We turn now to examine such approaches.

\section{(b) Institutional Approach}

The institutional approach assigns a firm to a regulator based on the firm's legal status and the regulator's legal authority. ${ }^{109}$ A bank falls within the purview of a prudential regulator, for example, while securities dealers fall within the responsibility of securities commissions and/or self-regulatory organizations. The functions of the respective regulator are established by statute, which creates legal divisions among regulators and their regulatory mandates. ${ }^{110}$ Many European countries, including France, Italy, Spain,

Overhauled", BBC News, 31 Mar 2013, BBC News Online <online:bbc.co.uk> Accessed 20 Oct 2013. See also The Turner Review, supra note 103 at 87 ("A balance between conduct of business regulation and prudential regulation which, with the benefit of hindsight, now appears biased towards the former. ... This failure to spot emerging issues was rooted in the paucity of macro-prudential, systemic- and system-wide analysis.")

${ }^{106}$ UK Financial Services Act, 2012 c21.

${ }^{107}$ Bank of England, "Prudential Regulation Authority", accessed 20 Oct $2013<$ online: http://www.bankofengland.co.uk>

${ }^{108}$ Wymeersch, supra note 13 at 250.

${ }^{109}$ Herring and Carmassi, supra note 93 at 57.

${ }^{110}$ Wymeersch, supra note 13 at 265. 
Portugal, and Greece, adopt an institutional approach. There are separate supervisory bodies for banks or credit institutions, investment firms and insurance companies as well as securities trading.

One could argue that the institutional approach applies to a certain extent in Canada. Along with having separate securities and prudential regulators in place, the federal government has also proposed the creation of a Cooperative Capital Markets Regulator (CCMR). Under this framework, participating provinces (Ontario and BC thus far) would enact uniform financial markets legislation within their jurisdictions. The federal government would enact legislation pertaining to systemic risk in financial markets and criminal law matters. A single regulator, governed by an expert board of directors, would administer both the federal and provincial legislation. The regulator is tasked with identifying and managing systemic risk, and would possess delegated authority to enact regulations, make orders, exercise emergency powers, and gather necessary information related to systemic risk. ${ }^{111}$ The regulator would report to a council of finance ministers of the participating jurisdictions. ${ }^{112}$ The advantage of this regulatory structure is that there is one institution within a country that is charged with managing systemic risk. With such an explicit mandate, there can be no doubt in times of financial crisis which body bears the authority to respond.

But this "sector by sector" approach does not readily apply to today's capital markets. Firms regularly operate across formal legal lines and may also be subject to the rules of more than one regulator. ${ }^{113}$ For example, banks are often subject to the rules of the prudential regulator while also subject to disclosure rules established and enforced by securities regulators. A further potential problem is that when statutes create multiple regulators to oversee markets, they can give rise to a "regulatory silo" issue whereby regulators do not communicate on issues of mutual concern to them, including systemic risk issues. This was obviously an issue during the financial crisis when no one regulator

${ }^{111}$ Government of Canada, Province of Ontario, and Province of British Columbia, "Agreement in Principle to Move Towards a Cooperative Capital Markets Regulatory System" (19 Sep 2013), available at $<$ http://www.fin.gov.on.ca/en/agreements/2013_09_19_agreement.pdf $>$ at 5-6.

${ }_{112}^{11}$ Ibid at 2.

${ }^{113}$ Wymeersch, supra note 13 at 260-261, 265. 
believed that it bore responsibility for addressing the massive market failures that occurred. ${ }^{114}$

The persistence of regulatory silos may give rise to failures in institutional coordination. Regulators may develop differing rules that apply to the same activity ${ }^{115}$ or they may fail to take into account all relevant issues given that their area of expertise is statutorily limited. These issues in turn may give rise to regulatory arbitrage opportunities whereby firms seek permission from one regulator to complete a transaction if there is a strong likelihood that another regulator would not permit the activity.

\section{(c) Functional Approach}

The functional approach focuses not on a regulator's legal authority or a firm's legal status but on the economic activity in which a firm engages. ${ }^{116}$ Unlike the institutional approach, the functional approach envisions that regulatory responsibility will be assigned based on the nature of market activity. For example, the U.S. Commodity Futures and Trade Commission regulates futures while the Securities and Exchange Commission regulates securities. ${ }^{117}$ Regardless of the nature of the firm, the regulator steps in depending on the type of economic activity.

Overlaps can arise between the institutional and functional approaches. The United States, for example, combines both functional and institutional approaches, further complicated by overlapping state and federal powers. ${ }^{118}$ Four federal agencies oversee

\footnotetext{
${ }^{114}$ See e.g. Anita Anand, "After the Reference: Regulating Systemic Risk in Canadian Financial Markets", in Anita Anand, ed., What's Next for Canada: Securities Regulation After the Reference (Toronto: Irwin Law, 2011) at X (referring to Canada's asset backed commercial paper crisis).

${ }^{115}$ Group of Thirty, supra note 13 at 34.

${ }^{116}$ Ibid at 24. The lines between categories may blur and some commentators use different terminology. For example, Wymeersch terms regulation-by-objective as the functional approach and places the "twin peaks" model within this category. See Wymeersch, supra note 13 at 258. See also Jeroen JM Kremers, Dirk Schoenmaker, and Peter J Wierts, "Cross-Sector Supervision: Which Model?" (2003) BrookingsWharton Papers on Financial Services 225 at 233.

${ }^{117}$ US Department of the Treasury, supra note 13 at 48.

${ }^{118}$ Group of Thirty, supra note 13 at 32.
} 
deposit-taking institutions. ${ }^{119}$ Moreover, state chartered banks fall under the supervision of federal and state regulators. ${ }^{120}$ States also separately regulate securities, although federal regulations pre-empt most state regulation. ${ }^{121}$ Finally, states oversee insurance activities. $^{122}$

Thus, one of the main difficulties with the functional approach relates to "line-drawing" between financial activities, particularly given the complexities that arise from financial innovation. ${ }^{123}$ Some would argue, for example, that futures as a type of derivatives contract are essentially securities and should be regulated as such. ${ }^{124}$ Further, as is the case with the institutional approach, multiple regulators under functional supervision may not have the information, jurisdiction, or coordinative capacity to address the NSR. ${ }^{125}$ Both the functional and institutional models likely involve interaction with multiple regulators, raising compliance cost concerns. Absent coordination among regulators, the functional approach may not be effective in addressing concerns that arise from the NSR.

The US sought to address the coordination and information problems evident in the 2008 financial crisis through the creation of the Financial Stability Oversight Council (FSOC), one of the reforms enacted by Dodd-Frank. ${ }^{126}$ FSOC is tasked with identifying and responding to systemic risks arising from bank and non-bank financial institutions, as well as promoting market discipline. ${ }^{127}$ The chair of FSOC, the heads of each of the eight federal institutions that regulate financial markets - including the Secretary of the

\footnotetext{
119 These are: regulators - the Office of the Comptroller of the Currency (OCC), the Federal Reserve (FRB), the Federal Deposit Insurance Corporation (FDIC), and the National Credit Union Administration. See US Department of the Treasury, supra note 13 at 32. The Office of Thrift Supervision was disbanded as part of the Dodd-Frank reforms; its functions were merged into the OCC, FRB and FDIC: See US Offices of the Inspector General, "Status of the Transfer of Office of Thrift Supervision Functions" (26 Sep 2012) at 2 .

${ }^{120}$ See Pan, supra note 12 at 866.

${ }^{121}$ US Department of the Treasury, supra note 13 at 55.

${ }^{122}$ Although Dodd-Frank established a Federal Insurance Office (within the Department of Treasury) with the goal of identifying systemic risk arising out of "issues or gaps in the regulation of insurers": US

Department of the Treasury, supra note 13 at 63-64. Dodd-Frank, supra note 18 at H.R. 4173-205

${ }^{123}$ Group of Thirty, supra note 13 at 35.

${ }^{124}$ See e.g. Expert Panel on Securities Regulation, Final Report and Recommendations (Ottawa: Government of Canada, 2009) at 56.

125 US Department of the Treasury, supra note 13 at 27. Group of Thirty, supra note 13 at 35.

${ }^{126}$ Dodd-Frank, supra note 18 at $\$ 111$.

${ }^{127}$ Ibid at $\$ 112$.
} 
Treasury, the Federal Reserve, the SEC, and the CFTC - and an appointee of the President, comprise the voting members of the council. ${ }^{128}$ Non-voting members include state banking, securities, and insurance regulators. ${ }^{129}$ Statutory duties include the collection and sharing of information between federal and state regulators, monitoring domestic and international regulatory developments and proposing new regulatory measures, and identifying systemically important (non-bank) financial institutions (SIFIs) to come under the authority (and prudential regulation) of the Federal Reserve. ${ }^{130}$ The regulatory authority of the Federal Reserve is thus expanded. ${ }^{131}$ The FSOC itself does not have regulation-making powers. At this stage, the performance of the relatively new organization is difficult to assess. In late 2013, FSOC designated three SIFIs: Prudential Financial, AIG, and General Electric Capital. ${ }^{132}$

\section{(d) Objectives-based Approach}

The objectives-based approach, also known as the "twin peaks" regulation, divides responsibility according to regulatory objective. ${ }^{133}$ It identifies three basic regulatory objectives that the regulatory architecture must address: macro-economic stability of the kind typically associated with central banks in terms of managing the money supply and acting as lender of last resort in maintaining liquidity in the financial system; microprudential regulation focused on the financial stability of particular financial institutions; and conduct of business regulation designed to protect consumers of financial services

\footnotetext{
${ }^{128}$ Ibid at $\S 111$.

${ }^{129}$ Ibid.

${ }^{130}$ Ibid at $\$ 112$.

${ }^{131}$ See Nellie Lang, "Systemic Risk Monitoring and Financial Stability" (2013) 45:1 Journal of Money, Credit and Banking 129 at 129-130.

${ }^{132}$ US Department of the Treasury, "Financial Stability Oversight Council" < treasury.gov> (Accessed 14 Mar 14) See also Financial Stability Oversight Council, "2013 Annual Report” (2013) at 3 which states: While the FSOC reports that some progress has been made in response to recommendations regarding the regulation of the shadow banking sector (particularly money market mutual funds and repurchase agreements), by its own admission there remains gaps and "important run risks in the financial system persist."

${ }^{133}$ Group of Thirty, supra note 13 at 24. See also US Department of the Treasury, supra note 13 at 142 . The lines between categories may blur and some commentators use different terminology. For example, Wymeersch terms regulation-by-objective as the functional approach and places the "twin peaks" model within this category. See Wymeersch, supra note 13 at 258.
} 
and investors in financial institutions, as well as arguably precluding or constraining excessively risky financial activities by financial institutions.

This model benefits from many of the coordination and cost advantages of the integrated approach, while differentiating between objectives that are widely seen to require distinct regulatory strategies. ${ }^{134}$ Business conduct regulation of financial institutions can be adversarial, while prudential regulation is often cooperative, solutions-oriented, and based on repeated interactions between regulators and regulatees. ${ }^{135}$ Unlike the integrated approach, an objectives-based model is likely less prone to one priority giving way to another (e.g., consumer protection prioritized over the soundness of financial institutions, or the converse). ${ }^{136}$ Indeed, the US Department of Treasury has argued that the effect of centralizing prudential regulation would be to strengthen the "focus on areas and institutions with the greatest potential for market failures in terms of limited market discipline." ${ }^{137}$ However, as several regulators would oversee different aspects of the same financial actor, one regulator's actions could have significant consequences on the other's regulatory capacity - making coordination all the more critical. ${ }^{138}$

Australia's regulatory structure is defined as a "twin peaks" model: the Australian Prudential Regulatory Authority (APRA) is tasked with prudential regulation and the Australian Securities and Investment Commission (ASIC) with business conduct regulation. ${ }^{139}$ These institutions are in addition to the Reserve Bank of Australia (RBA) and the Treasury (or Department of Finance). ${ }^{140}$ The implementation of IOSCO principles including reforms of the OTC derivative markets, make the ASIC responsible for addressing certain systemic risks. ${ }^{141}$ Coordination is carried out through the Council

\footnotetext{
${ }^{134}$ Pan, supra note 12 at 820.

${ }^{135} \mathrm{Ibid}$ at 820 . A similar relationship is described by Anand and Green regarding prudential regulation of Canada's banking system. See Anita Anand and Andrew Green, "Regulating Financial Institutions: The Value of Opacity" (2011) 7 McGill LJ 399 at 406, 424-425.

${ }^{136}$ Group of Thirty, supra note 13 at 38.

${ }^{137}$ US Department of the Treasury, supra note 13 at 142.

${ }^{138}$ Pan, supra note 12 at 821; US Department of the Treasury, supra note 13 at 142.

${ }^{139}$ See The Group of Thirty, supra note 13 at 31 .

140 "Macroprudential Analysis and Policy in the Australian Financial Stability Framework" (2012) Australian Prudential Authority and the Reserve Bank of Australia at 2.

${ }^{141}$ Ibid at 3 .
} 
of Financial Regulators, a non-statutory body comprised of the four bodies (Chaired by the RBA), but has no independent regulatory functions. ${ }^{142}$

"Twin peaks" is something of a misnomer: countries that adopt an objectives-based approach typically involve a third "peak" or institution in the central bank, which continues to have responsibility over monetary policy and currency. ${ }^{143}$ In fact, under all structures of financial supervision, the central bank plays this role, executing monetary policy, overseeing payment systems, and acting as a lender of last resort. ${ }^{144}$ Similarly, under all models the Treasury implements fiscal policy and reports to elected leadership or Parliament. That said, a country's regulatory structure may impact the responsibilities of the central bank and Treasury. For example, one version of the integrated approach tasks the central bank with responsibility for both market stability and prudential regulation. $^{145}$

\section{(e) Analysis}

We note overlap among the four approaches. In Canada, for example, financial supervision has both institutional and objectives-based components: separate agencies regulate banking, insurance, and securities activities, suggesting a functional approach. ${ }^{146}$ But within banking and insurance activities, a more objectives-based form of regulation is observed. The Office of the Superintendent of Financial Institutions (OSFI) is the prudential regulator of banks (an exclusive federal responsibility) and federally regulated insurance companies. ${ }^{147}$ Business conduct regulation of banking is tasked to the federal Financial Consumer Agency of Canada (FCAC). ${ }^{148}$ While the FCAC provides limited business conduct regulation of federally incorporated insurance companies, the bulk of

\footnotetext{
${ }^{142}$ Ibid at 3 .

${ }^{143}$ Anita Anand, Nathan Halmrast and Albert Yoon, "Central Bank Mandates" (2013) [unpublished manuscript on file with authors].

${ }^{144}$ See generally Wymeersch, supra note 13 at 243.

145 See e.g. The Turner Review, supra note 103 at 91.

${ }^{146}$ Pan, supra note 12 at 822.

147 Office of the Superintendent of Financial Institutions Act RSC 1985 c. 18 (3rd Supp) at s 4.

${ }^{148}$ Financial Consumer Agency of Canada Act SC 2001 c9 at s 3(2); Christopher C Nicholls, "Financial Institutions: The Regulatory Framework" (Markham, ON: LexisNexis Canada, 2008) at 27-28. Pan, supra note 12 at 822-833.
} 
business conduct regulation of both provincially and federally incorporated insurers is carried out by individual provincial agencies for insurance activity within their jurisdiction. ${ }^{149}$

We also note certain difficulties with each model. The integrated approach is impractical for many states given their political structure and risks subordinating important objectives to others that may at any given time be deemed to take precedence. The institutional model has become obsolete, as many financial institutions operate across traditional financial boundaries. While the functional approach may have some advantages over the institutional approach, it entails multiple regulators regulating various classes of activities of given financial institutions, without any holistic or integrated perspective on the financial health of an institution. The objectives-based approach is perhaps the most likely to permit coordination across regulatory lines in a way that allows the NSR to be monitored and regulated.

The objectives-based approach, however, leaves important questions to be resolved, especially in terms of the regulation of the NSR. For example, should the central bank also be the micro-prudential regulator? If macro-economic policy formulation and implementation is to be separated from micro-prudential regulation, how are capital adequacy and liquidity requirements for various kinds of financial institutions to be established, and by whom? Moreover, given that these two functions are very closely related and highly inter-dependent, how should two separate agencies coordinate their activities? That is, it is obviously highly salient for central banks to be aware that a major financial institution is at risk of failing, and may require liquidity support or even a bailout, which information is likely to be more centrally within the mandate of the microprudential regulator.

This analysis of the four approaches to financial market regulation suggests that while numerous regulators have a role to play in the regulation of the NSR, that role necessarily varies depending on the institutional and legal structure in place in a given country. In our

\footnotetext{
${ }^{149}$ Nicholls, supra note 148 at 109.
} 
view, the most promising approach is to establish the objectives to be achieved and determine which institutions will be charged with pursuing these objectives, understanding that the three main objectives on which financial systems must focus related to: macroeconomic factors, microprudential policy, and dealer regulation (i.e. consumer or investor protection). We argue in favour of coordination and especially information sharing among the domestic regulators charged with administering these objectives. Thus, the regulatory design that a country adopts, and the extent to which the relevant legislation facilitates coordination among all regulators in the system, is crucial.

\section{International Mechanisms}

As a concept, NSR encompasses more financial institutions than commercial banks and more instruments of intervention than simply prudential requirements. It also recognizes the cross-border contagion effects of domestic actors including banks, hedge funds and, of course, public corporations. Though we may easily agree that the concept of systemic risk has evolved and broadened in this way, the challenge of achieving better domestic

and international co-ordination of multiple regulators persists. In this section, we examine international mechanisms of coordination and integration of financial sector regulation, with a view to better regulating the NSR that increasingly spills over national borders as financial institutions become global and financial transactions are often international in scope. We examine the institutional architecture for mitigating NSR, discussing oversight or coordinating mechanisms at the international level. We conclude by arguing that international coordination needs to be improved and propose ways in which this might evolve.

\section{(a) International Institutions}

Historically, international institutions tended to follow an institutional segmentation model which included: the Basel Committee on Banking Supervision for commercial banks, an international association of insurance regulators, and IOSCO in the area of securities regulation. International coordination efforts accelerated in response to the 
financial crisis, which demonstrated that systemic risk in one country, and even in one segment of the market, has potentially devastating international consequences. ${ }^{150}$ Coordinated international regulation of NSR is thus of critical importance and even more so in face of possible regulatory arbitrage among domestic supervisory structures. ${ }^{151}$ That is, not only does global interconnectedness mean that a financial crisis has implications for the economies of other countries, a regulatory gap or failure in one jurisdiction imposes a negative externality on other jurisdictions' economies.

During the financial crisis, the G20 assumed a more prominent "agenda setting" role in international financial regulation. ${ }^{152}$ It acts as a political forum for framework agreements on macroeconomic policy (e.g., stimulus, deleveraging, exchange rate flexibility), ${ }^{153}$ and provides policy direction to the Financial Stability Board (FSB). Established by the G20, the FSB coordinates national financial regulators and international standard setting bodies, ${ }^{154}$ and effectively translates G20 policies into more technical directives to standard setting bodies (for example, with regards to OTC derivatives ${ }^{155}$ and regulation of the shadow banking system ${ }^{156}$ ). The FSB's state membership is somewhat broader than the G20, and includes international organizations such as the Bank of International Settlements (BIS), the World Bank and the IMF. ${ }^{157}$ International standards for banking, securities, and insurance regulation are coordinated through the Basel Committee on Banking Supervision, IOSCO, and the International Association of Insurance Supervisors respectively. ${ }^{158}$

\footnotetext{
${ }^{150}$ Robert Lavigne and Surata Sarker, "The G20 Framework for Strong, Sustainable and Balanced Growth: Macroeconomic Coordination Since the Crisis" (Winter 2012-2013) Bank of Canada Review at 2. See also Lorenzo Bini Smaghi, "What has the financial crisis taught us? The global dimension and international policy cooperation" (6-8 September 2010) Speech to 21st Century Forum 2010 (Beijing).

${ }^{151}$ Barry Eichengreen, "International Financial Regulation After the Crisis" (2010) Daedalus 107 at 107108.

${ }^{152}$ Chris Brummer, Soft Law and the Global Financial System (New York: Cambridge University Press, 2012) at 68.

${ }^{153}$ Lavigne and Sarker, supra note 150 at 3-4.

154 "Charter of the Financial Stability Board" (June 2012) Financial Stability Board at Art 1 and Art 2.

${ }^{155}$ See generally OTC Derivatives Reforms Progress" (2 Sep 2013) Financial Stability Board.

${ }^{156}$ See generally "Strengthening Oversight and Regulation of Shadow Banking" (29 August 2013) Financial Stability Board.

157 "Links to FSB Members" Financial Stability Board <online: www.financialstabilityboard.org> (Accessed 8 Nov 2013); See also Stavros Gadinis, "The Financial Stability Board: The New Politics of International Financial Regulation (2013) Texas International Law Journal 157 at 158.

${ }^{158}$ Herring and Carmassi, supra note 93 at 71.
} 
While setting standards is unquestionably important, ensuring compliance with international standards presents further challenges. The World Bank and IMF have been tasked with reporting on domestic compliance with international standards and principles, with individual states playing a role through a peer review process. ${ }^{159}$ All monitoring is conducted through the Financial Assessment Sector Assessment Program, a voluntary process for all states. ${ }^{160}$ Because of concerns with non-compliance, countries have decided that the 25 most systemically critical states undergo a stability assessment every five years. ${ }^{161}$ This peer review process is one that we favour, as discussed below.

Quite apart from stability assessments, enforcement has historically been problematic in the international financial arena. The Basel frameworks, for example, have been called a failure for their inability to regulate bank capital and for allowing extreme rates of leverage while ignoring a burgeoning shadow banking system. ${ }^{162}$ One European Central Bank member has noted that while finance was global, regulation was based on selfcontained national regulation; the lack of common international rules encouraged regulatory arbitrage; and weak risk monitoring was prevalent. ${ }^{163}$ But it is difficult to conclude definitively that more effective global coordination would have been effective in mitigating issues that led to the crisis. Citing the original Basel framework, some have expressed concern that these international efforts, which are by necessity driven by consensus, lead to "lowest common-denominator regulation." ${ }^{164}$ Nevertheless, we believe that reform proposals (domestic and international) surrounding the NSR are unlikely to be effective in the long-term without some structure in place for international coordination.

\footnotetext{
${ }^{159}$ Brummer, supra note 152 at $68-69$.

${ }^{160}$ International Monetary Fund, "Financial Sector Assessment Program: Frequently Asked Questions" (5 Aug 2013) Accessed (20 Jan 2014) <online: http://www.imf.org/external/np/fsap/faq/\#q16>

${ }^{161}$ International Monetary Fund, "Factsheet: The Financial Sector Assessment Program” (4 Sep 2013) Accessed (20 Jan 2014) <online: http://www.imf.org/external/np/exr/facts/fsap.htm>

${ }^{162}$ Eichengreen, supra note 151 at 107-111-112.

${ }^{163}$ Smaghi, supra note 150.

164 Eichengreen, supra note 151 at 110.
} 


\section{(b) Proposals for International Coordination and Enforcement}

Most critics of the existing international framework argue that the bulk of the problems lie in weak prudential supervision, rather than in the organization or effectiveness of standard-setting bodies. ${ }^{165}$ But many of the suggestions for an institutional order do not address the fact that a differing conception of systemic risk - what we have termed the "new systemic risk" - is in play. They thus focus on the reform of financial institution governance alone, rather than the entire financial system under which coordination among separate regulators charged with separate tasks is central (at the very least) for information sharing purposes. Rolf Weber, for example, proposes a "college of supervisors" to supervise cross-border financial institutions. ${ }^{166}$ The college would be a working group comprised of domestic supervisors of international financial institutions. It would conduct prudential monitoring of institutions and would be considered an additional layer of governance rather than being in a subordinate or hierarchical relationship to state supervisors. ${ }^{167}$ Similarly, Eric Pan proposes the creation of a new international prudential regulator, whose power would be delegated from the collective supervisory authority of national regulators. ${ }^{168}$ The new regulator would be focused only on cross-border financial institutions, and would be operationally independent from states, comprised as an expert body with enforcement powers. ${ }^{169}$

Our analysis of the NSR suggests that prudential regulation alone, whether administered on a national or international basis, will be insufficient to monitor and regulate such risk; systemic risk is no longer an issue of prudential regulation alone. Rather, a regulatory approach that attempts to coordinate multiple domestic regulators across multiple countries is likely required. We favour using memoranda of understanding (MOU) to

\footnotetext{
${ }^{165}$ The literature distinguishes between regulation (standard-setting) and supervision (monitoring and compliance). See Luis Garicano and Rosa M Lastra, "Towards a new architecture for financial stability: seven principles", in Thomas Cottier, John H Jackson, and Rosa M Lastra, eds, International Law in Financial Regulation and Monetary Affairs (Oxford: Oxford University Press, 2012) at 73.

${ }^{166}$ Rolf H Weber, "Multilayered Governance in International Financial Regulation and Supervision", in Cottier et al, eds, supra note 159 at 168.

${ }^{167}$ Ibid at 169.

${ }^{168}$ Eric J Pan, "Challenge of International Cooperation and Institutional Design in Financial Supervision: Beyond Transgovernmental Networks" (2011) 11 Chi J Int’l L 243 at 273.

${ }^{169}$ Ibid.
} 
regulate the NSR. A loose network of international institutions is responsible for various aspects of financial oversight. The G20 and Financial Stability Board determine policy direction, for example, but neither can coordinate the implementation of these standards across countries. We argue that countries should voluntarily enter into MOUs with each other to bind them to both monitoring and coordinating on systemic risk issues. Regarding OTC derivatives, for example, countries would seek a commitment at the national level from each member country to reach agreement about trade repositories and/or central counterparty clearing (with assistance no doubt from domestic regulators where needed). At present, countries are pursuing individual initiatives in this area that are not necessarily harmonized with each other.

The question that would then arise is which body, if any, would play an enforcement role if countries violate their obligations under an MOU? Three options present themselves. The first alternative is for individual countries to decide whether there will be domestic enforcement in case of violations of global standards. This option is a "path of least resistance" of sorts and would not likely result in effective coordination among countries in the long-term, given countries' willingness to defect in cases where it is in their own self-interest to do so. Countries may walk a grey line by choosing to "cherry pick" from the international rules or under-enforce them. ${ }^{170}$

A second alternative would be to create a new governing body to play a coordinating and enforcement role not simply in the area of prudential supervision and enforcement but in all areas of financial regulation as specified in the MOU or treaty. Along these lines, Eisengreen calls for the creation of an international financial regulator-structured in the same general manner as the World Trade Organization - to establish and enforce principles upon member states. ${ }^{171}$ Kern and Dhumale propose a global financial

\footnotetext{
${ }^{170}$ See Brummer, supra note 152 at 135-136 (referring to the ways in which states may defect from enforcing international standards domestically, including "cherry picking" or under-enforcing standards); Joel P Trachtman, "The International Law of Financial Crisis: Spillovers, Subsidiarity, Fragmentation and Cooperation" in Cottier et al, eds, supra note 159 at 201 (on weighing the incentives to defect from enforcing international standards).

${ }^{171}$ Eichengreen, supra note 151 at 113-114.
} 
governance council to be established under a multinational treaty. ${ }^{172}$ Treaty signatories would agree to meet standards developed by delegated standard-setting institutions such as Basel, IOSCO, etc. - which would largely be left unchanged. ${ }^{173}$ The signatories could opt out of standards in certain cases, such as when it would undermine domestic financial stability. ${ }^{174}$ The council would be comprised of any willing state, thus moving out of the G20 "agenda setting” model. Supervision (i.e., monitoring and compliance) would remain with domestic authorities. ${ }^{175}$ This proposal does not include enforcement as one of the roles of the international body. But we believe that some type of enforcement, even if it consists of peer reviews that compel or incentivize countries and their financial institutions to follow international standards, is precisely what is missing in the international arena.

Whether or not it is charged with enforcement powers, the creation of a new international body would entail significant costs that may not be outweighed by the benefits of the new organization. While countries gain some status in taking membership in such organizations, they are likely to be reticent in implementing the policy recommendations of these organizations holus bolus. They may not, therefore, yield to attempts by the organization to enforce its rules and standards by applying sanctions and settling disputes through adjudication. IOSCO is a clear example of an international organization that has numerous members and sets standards that members aim to follow. ${ }^{176}$ Yet IOSCO has no remit to undertake enforcement actions against its members for failing to implement its recommendations. Its membership may decline if it attempted to do so.

A final alternative is to utilize existing international organizations, such as the IMF, the FSB or IOSCO, to manage NSR. Under this alternative, countries would comply with obligations under an MOU or treaty into which they enter voluntarily. The costs of setting up an oversight program would be less than under the second alternative because

\footnotetext{
${ }^{172}$ Alexander Kern and Rahul Dhumale, Global Governance of Financial Systems (New York: Oxford University Press, 2006) at 172.

173 Ibid at 164 .

${ }^{174}$ Ibid at 162 .

175 Ibid at 169-170.

${ }^{176}$ IOSCO has members from over 100 different countries. These members regulate more than 90 percent of the world's securities markets.
} 
countries would be using a current organization in which they are members, including its infrastructure and bureaucracy. Countries would agree to coordinate their oversight efforts and share information regarding relevant NSR issues that come to their respective attention. Essentially, they would agree to alter the mandate of the existing organization and to abide by its standards and ex post reviews, including peer review assessments by other countries.

Along these lines, Garciano and Lastra seek to make the IMF a global sheriff. ${ }^{177}$ They argue for a shift towards a hierarchical structure modeled after the WTO, with similar dispute settlement and enforcement powers. This proposal is potentially effective as it builds on the backbone of a relatively successful global organization that provides a framework for countries' conduct in negotiating and formalizing trade agreements as well as a dispute resolution process. Indeed, the financial services annex may be appealing as a model to follow in the international realm of financial institution regulation. The main difficulty with this model, however, is that the dispute resolution process can take years to complete and may be impractical in financial markets that can move significantly and quickly on the basis of just one piece of information. It is impractical to expect that a WTO-type process can be transplanted to the financial services sector.

We note that the objectives-based approach favoured above is agnostic on increased enforcement of NSR in the international sphere. Even with institutions charged with pursuing specific objectives in place on a national level, a global enforcement regime for NSR remains a missing piece of the puzzle and may raise legitimate concerns. Some states, for example, may not wish to cede control for financial supervision on sovereignty grounds, engaging similar debates as free trade and WTO reforms. They may also be critical of the regulatory convergence sought in enforcement mechanisms. They may, for example, see financial stability goals and a new form of global regulation as inconsistent

\footnotetext{
${ }^{177}$ Garicano and Lastra, supra note 165 at 92.
} 
with their own priorities, domestic or international. ${ }^{178}$ Yet, there is a middle ground between hard sanctions at the international level and no enforcement at all.

Occupying this middle ground is "soft law," a legitimate basis for institutional reform in the international sphere. "Soft law" refers to the plethora of non-binding international agreements, guiding principles, and best practices that seek to strengthen oversight and regulatory coordination of financial markets. ${ }^{179}$ Soft law is proving to be modestly effective in achieving harmonization in countries' financial market regulation. For example, the FSB's peer review process, wherein a team of experts reviews and reports on a state's compliance with international guidelines, has been successful in seeking to promote consistent implementation of post-crisis G20/FSB financial reforms. ${ }^{180}$ Another example is IOSCO's Multilateral Memorandum of Understanding (MMOU), which requires signatories to share information with other securities regulators necessary in facilitating the investigation or prosecution of securities infractions. With some success, IOSCO has used various tactics ratify and implement the MMOU, including offering technical assistance and "naming and shaming" non-compliant jurisdictions. ${ }^{181}$ In short, because soft law responds to countries' incentives to remain compliant with international standards relating to financial market regulation, it can be effective. The incentive is powerful because countries and their institutions do not wish to experience the flight of capital and credit or increased cost of capital that may persist if investors and depositors lose faith in financial markets.

Ferran and Alexander highlight the benefits of soft law, which include lower financing costs for a country's sovereign debt as well as more favourable financing terms for its

\footnotetext{
${ }^{178}$ See generally Dani Rodrik, The globalization paradox: why global markets, states, and democracy can't coexist (New York: Oxford University Press, 2012).

${ }^{179}$ See generally Eilis Ferran and Kern Alexander, "Can Soft Law Bodies be Effective? Soft Systemic Risk Oversight Bodies and the Special Case of the European Systemic Risk Board" (2011) University of Cambridge Faculty of Law Working Paper No 36; See also Brummer, supra note 152.

${ }^{180}$ Financial Stability Board, "Peer Review of the United Kingdom" (2013) FSB.

${ }^{181}$ See International Organization of Securities Commissions "Multilateral Memorandum of Understanding Concerning Consultation, Cooperation and the Exchange of Information" (2012 revised) < http:/www.iosco.org/library/pubdocs/pdf/IOSCOPD386.pdf>; Janet Austin, "IOSCO’s Multilateral Memorandum of Understanding Concerning Consultation, Cooperation and the Exchange of Information" (2012) 23 Criminal Law Forum 393 at 405; International Organization of Securities Commissions, “Annual Report" (2012) IOSCO at 29.
} 
financial institutions. By conforming to soft law such as FSB principles or Basel criteria, financial institutions signal their financial stability to global markets. ${ }^{182}$ Soft law also allows for flexibility in implementation; unlike hard law, it is not "directly enforceable [and] can be more open-textured." ${ }^{, 183}$ While soft law has its drawbacks, including an inability to constrain those countries and financial institutions that violate international standards, it also has benefits. It can lead to meaningful change in the short-term while countries may take years to agree to implement a hard-law based regime let alone the substantive components of that regime. ${ }^{184}$

We agree that global financial reform is extraordinarily difficult to effect for various political, legal, and economic reasons. That is, there is a certain path dependence that restricts major shifts in the institutional landscape from both a standard-setting and an enforcement perspective. As noted above, path dependence is driven by a series of selfreinforcing mechanisms that disincentivize the adoption of different institutional arrangements. As an example, setting the constitutional debate aside, the persistence of a decentralized regime of Canadian securities regulation (i.e., ten separate securities regulators) could be seen in many respects as a product of switching costs. Several provincial governments (including Quebec and Alberta), with the support of their business sectors, opposed changes on the grounds that it would hinder local economic development and employment, and limit the growth of local firms in the legal, accounting, and banking sectors. ${ }^{185}$ Thus, switching costs could be rooted in a combination of political economy considerations, learning costs (knowledge that has been built up in local securities commission) and network effects (impact on groups that rely upon a local commission). ${ }^{186}$

\footnotetext{
${ }^{182}$ Ferran and Alexander, supra note 179 at 6.

183 Ibid.

${ }^{184}$ See also Kenneth W Abbott and Duncan Snidal, "Hard and Soft Law in International Governance" (203) 54 International Organization 421 at 444-446.

${ }^{185}$ Nicolas Van Praet, “Quebec business community ramps up calls to cancel national securities regulator plans" Financial Post (21 Nov 2013); Fight brewing over securities watchdog plan Globe and Mail (15 Jun 2010) B4.

${ }^{186}$ See Prado and Trebilcock, supra note 20 at 370.
} 
But major economic shocks provide a window for such overhauls. The 2008 financial crisis, for example, led the UK government to shift from an integrated structure to an objectives-based form of regulation. The US eliminated a federal agency (the Office of Thrift Supervision) and established the Financial Stability Oversight Council and the Consumer Financial Protection Bureau as part of their Dodd-Frank reforms. Canada is in the midst of establishing a regulator with authority over systemic risk among participating provinces, a process that arguably began in $1935 .{ }^{187}$ At the international level, facing an international economic downturn, the G20 repositioned the FSB and accelerated policy reforms, effectively directing changes to regulatory standards through organizations such as Basel Committee on Banking Supervision and IOSCO. ${ }^{188}$ Thus, the 2008 financial crisis could be seen as a critical juncture, the "brief moment" that can alter the course of institutional development. ${ }^{189}$ Of course, the changes adopted during such a moment, as Prado and Trebilcock note, "[are] not a guarantee that good ideas will be adopted." 190 The reforms in the United States, for example, fall significantly short of earlier US Department of Treasury recommendations to adopt an objectives-based structure of financial supervision, and it is not clear whether reforms are capable of preventing future systemic shocks. International regulatory efforts remain constrained by non-compliance. Nevertheless, these examples of institutional restructuring imply that scholars and regulators should not discount reform simply because of institutional "stickiness."

\section{Conclusion}

The 2008 financial crisis sparked a series of policy responses by financial regulators aimed at, inter alia, increasing disclosure, reducing the adverse incentives of credit rating agencies, ensuring a clearing facility for the OTC derivatives market, and making securitizations more transparent. But beyond triggering policy efforts, the crisis further exposed the extent to which financial institutions are interconnected, cross formerly

${ }^{187}$ See Reference Re Securities Act, 2011 SCC 66, [2011] 3 SCR 837 at para 12.

${ }^{188}$ See Sungjoon Cho and Claire R Kelly, "Promises and Perils of New Global Governance" (2012) 12 Chicago Journal of International Law 491 at 552.

${ }^{189}$ See Prado and Trebilcock, supra note 20 at 358.

${ }^{190}$ Ibid at 369 (emphasis in original). 
strictx business lines, and are increasingly international in the scope of their activities and impacts. Rather than focusing simply on the relative financial positions of individual financial institutions (classically banks), financial regulators must address new systemic risk - macroprudential risks resulting from financial contagion emanating from a triggering event or exogenous shock.

Containing and managing this new form of systemic risk presents coordination challenges both domestically and internationally. In many states, NSR implicates multiple domestic regulators. In Canada, for example, addressing systemic risk requires coordination between the federal prudential regulator (OSFI), ten provincial securities regulators, and the Bank of Canada. The United States has an even more complicated regulatory structure. Similarly, at the international level, cross-border contagion requires a coordinated response among international standard-setters. The voluntary and informal nature of these international arrangements presents an additional problem in monitoring and enforcement of these standards.

Ultimately, we argue that the coordination challenges presented by NSR suggest a need for institutional reform in the structure of financial supervision but that any reform is likely to be incremental. At the domestic level, we argue that the objectives-based approach is the most likely to facilitate the coordination necessary to mitigate NSR while allowing uncompromised prudential and business conduct regulation. This approach has been adopted in Australia and more recently the UK. We also argue for greater emphasis on coordination among domestic financial regulators, rather than simply focusing on prudential regulators alone and expecting these regulators to be solely responsible for the NSR. At the international level, we propose an expanded use of soft law including memoranda of understanding (MOU) among countries to bind them to a system of monitoring and managing the NSR. 